\title{
Principal Authentic Leadership Survey
}

\author{
Nurdelima Waruwu*, Mukhneri Mukhtar, Sukro Muhab \\ Educational Management Program \\ Universitas Negeri Jakarta \\ Jakarta, Indonesia \\ *nurdelimawrw@gmail.com
}

\begin{abstract}
This research aims to explain madrasah aliyah principal authentic leadership which has been implemented by the principals. The research used survey method by distributing questionnaires through Google forms which then were analyzed descriptively. These questionnaires were distributed to all private Islamic senior high school (Madrasah Aliyah) teachers in West Java, Indonesia. Results of the research show that the authentic leadership dimensions consisting of self-awareness, transparent relationship, balanced processing, moral perspective, empathy, critical thinking and thinking about oneself has been implemented by different presentation. By this research, it is expected to be an illustration of principal leadership type implementation which can be used as a reference to lead schools so that there will be excellence and competitive schools.
\end{abstract}

Keywords-authentic leadership, islamic senior high school, leadership, Madrasah Aliyah, principals

\section{INTRODUCTION}

Madrasah as an Islamic school faces a number of problems in its effort to create unique and distinguished value so students or students' parents are interested to study at the schools. There are a few founders of this religion-based school. There are some problems faced by Islamic school, among others are (1) very limited training programs for teachers, (2) adequate curriculum based on needs and demands, for example common Islamic curriculum, not Islamic according to different ideology or interpretation of certain groups in Islam, (3) many unprepared or untrained teachers, (4) the absence of qualified, actual and contextual text books, reconfirming on the importance of context, (5) less open and reflective traditional syllabus [1]. These various problems cause difficulty for madrasah to manifest as the main choice for parents and students.

Quality achievement in religious education implementation is seen as a process facing tough obstacles. There is such difficulty to manifest Islamic education goals either goals for faith and Islam or also education quality, then there is also a pressure given by Islamic school founders which leads to the following concerns: (1) Islamic schools are mostly exclusive which gives difficulty for integration, (2) there is doctrine for ideas of anti-West, anti-democracy, and anti-integration. Usually, existence of religious schools is required particularly since students and parents or their minority religion have a sense of isolated in urban school [2].

In Indonesia, implementation of religious education and religion has been regulated in Regulation of Government No. 55 of 2007 concerning Religious and Religion Education. Meanwhile for implementation of madrasah, it is regulated in Regulation of Minister of Religion of the Republic of Indonesia No. 90 of 2013 concerning Implementation of Madrasah Education. Based on the regulation, in legality, Madrasah Aliyah (MA) is equal to public schools. In Indonesia, there are only some Islamic schools considered as the main selection since public community think that Madrasah Aliyah (MA) quality is still left behind. Education in MA is assessed to be ineffective by lack of teacher performance, leadership and teacher professional orientation in applying their tasks [3]. Islamic school puts aside contextual as an important part of all education [4].

Positioning as an excellent madrasah can be formed by some ways among others by differentiation of created values, both by conformity to market demands or owned resources, and also by quality management system in its management. The management system is greatly determined by principals. Currently, organization needs are for authentic leadership. Authentic leadership is a leader for people and visionaries of future [5].

Authentic leadership is a form of leadership based on integration and transparency as a result of clarification following a series of trusts taken from morality value having self-reflection structure on reality based on ethical values [6-8]. Authentic leadership is able to create a healthy and secure work environment by supporting psychological capital as a mediator variable for each individual in the organization optimally [9]. Authentic leaders serve as leaders with full self-awareness in thinking and acting as well as are perceived as a conscious person to self-moral values and other moral; having broad insight and having strength; aware of any context where he is, having self-confidence, expectation, optimism, toughness and high moral character [10]. Indicators of authentic leadership describes how self-awareness contextually. In the same context, namely education, it is said that "The foundation of authentic leadership is authenticity". It is indicated by the existence of "1) selfawareness, 2) relational transparency, 3) balanced processing 4) internalized moral perspective" [11]. An authentic leader is 
illustrated to have empathy showing self-affective response, emotional regulation, perspective taking, and empathy to others [12].

Regarding leadership at school, principal leadership is related to personality and values. Principal basic assumptions at school are behavior an ethical leadership to achieve shared goals or by organizational members and designed system [13]. Principals show differences as a leader with a manager. The difference lies on his visionary views and attempts to break down systems that actually hinder the achievement of educational goals. Leaders carry out functions as communicators of strategic issues in order to realize the vision, inspire quality management functions such as planning, organizing, implementing and evaluating systems and quality policies in accordance with the direction towards the vision. The principal as a leader directs and inspires efforts to realize the vision and mission of the school.

Role of the principal determines school success or failure to implement its role in realizing educational goals. Meanwhile, $80 \%$ of the problem of low quality is determined by management, while the remaining of $20 \%$ is determined by other factors [14]. This means that almost all high quality schools can be led by high quality principals as well. Principal success as a leader is largely determined by his professionalism. However, the reality in the field shows that there are still many school principals who do not carry out their duties and functions as educational leaders because the appointment process is not transparent, principal mentality is characterized by a lack of motivation and enthusiasm and lack of discipline in carrying out tasks, and often arriving late as well as other inhibiting factors to improve the quality of education; all of which imply low school work productivity which also has implications for low level of quality. This implies school low work productivity which has implications for quality (input, process and output).

From this explanation, it is clear that the optimization of the function of the quality management system in the management of education is directly proportional to how the leadership pattern is applied by the principal in each school. However, more comprehensive and specific research on authentic leadership has not been carried out, especially at the Islamic senior high school. For this reason, researchers are interested in conducting principal authentic leadership survey for each of the dimensions including self-awareness, transparent relationship, balanced processing, moral perspective, empathy, critical thinking, and thinking about oneself so that it can determine how to describe the quality of authentic leadership of private madrasah aliyah principals in West Java.

\section{Research Methodology}

The method used in this research is descriptive quantitative method with a survey. The probability sampling method with simple random sampling was used to determine the final number of respondents as many as 32 people. By this method, it is expected that researchers will be able to get an overview of principal authentic leadership quality. In data collection, the researchers used questionnaires with the research objects are private Islamic senior high school (Madrasah Aliyah) teachers in West Java. The sampling was carried out using a proportional sampling technique, namely sample determination was carried out by taking representatives from each group in the population whose numbers were adjusted to the number of the subject in each of these groups. The data obtained were then analyzed using frequency analysis and histograms so that it can draw the percentages for each indicator in each dimension of the principal's authentic leadership.

\section{RESUltS AND DisCUSSION}

Based on these authentic leadership dimensions, results of the survey show an illustration of private madrasah principal authentic leadership quality in West Java as the following (figure 1). 


\begin{tabular}{|c|c|c|c|}
\hline $\begin{array}{l}\text { Authentic Leadership } \\
\text { Dimensions }\end{array}$ & Pie Diagram & Results & Criteria \\
\hline \multirow[t]{5}{*}{ Self-awareness } & \multirow{5}{*}{$\varpi \mathrm{TP} \backsim \mathrm{JR} \backsim \mathrm{KD} \approx \mathrm{SR} \backsim \mathrm{SL}$} & $64.34 \%$ of most principals show self-awareness attitude. & Excellence \\
\hline & & $24.84 \%$ of principals often show self-awareness attitude. & Good \\
\hline & & $7.56 \%$ of principals sometimes show self-awareness attitude. & Quite good \\
\hline & & $2.16 \%$ of principals rarely show self-awareness attitude. & Less good \\
\hline & & $1.08 \%$ of principals never show self-awareness attitude. & Not very good \\
\hline \multirow{5}{*}{$\begin{array}{l}\text { Transparent } \\
\text { relationship }\end{array}$} & \multirow{5}{*}{$₫ T \mathrm{TP} \equiv \mathrm{JR}=\mathrm{KD} \equiv \mathrm{SR} \equiv \mathrm{SL}$} & $62.2 \%$ of most principals always show transparent relationship. & Excellence \\
\hline & & $\mathbf{2 4 . 9 8 \%}$ of principals often show transparent relationship. & Good \\
\hline & & $11.48 \%$ of principals sometimes show transparent relationship. & Quite good \\
\hline & & $0 \%$ of principals rarely show transparent relationship. & Less good \\
\hline & & $1.35 \%$ of principals never show transparent relationship. & Very not good \\
\hline $\begin{array}{l}\text { Authentic Leadership } \\
\text { Dimensions }\end{array}$ & & Results & Criteria \\
\hline \multirow[t]{5}{*}{ Balanced processing } & \multirow{5}{*}{$\| T P=J R=K D=S R=S L$} & 62.2\% of most principals always show balanced processing. & Excellence \\
\hline & & $29.03 \%$ of principals often show balanced processing. & Good \\
\hline & & $8.1 \%$ of principals sometimes show balanced processing. & Quite good \\
\hline & & $0.68 \%$ of principals rarely show balanced processing. & Less good \\
\hline & & $0 \%$ of principals never show balanced processing. & Not very good \\
\hline \multirow[t]{5}{*}{ Moral Perspective } & \multirow{5}{*}{$\| T P \equiv J R=K D \equiv S R \equiv S L$} & $65.8 \%$ of most principals always show moral perspective. & Excellence \\
\hline & & $28.8 \%$ of principals often show moral perspective. & Good \\
\hline & & $4.5 \%$ of principals sometimes show moral perspective. & Quite good \\
\hline & & $0.9 \%$ of principals rarely show moral perspective. & Less good \\
\hline & & $0 \%$ of principals never show moral perspective. & Not very good \\
\hline \multirow[t]{5}{*}{ Empathy } & \multirow[b]{5}{*}{$=T P \equiv J R=K D=S R \equiv S L$} & $64.23 \%$ of most principals are always able to empathy. & Excellence \\
\hline & & $28.35 \%$ of principals are often able to empathy. & Good \\
\hline & & $6.08 \%$ of principals are sometimes able to empathy. & Quite good \\
\hline & & $1.35 \%$ of principals are rarely able to empathy. & Less good \\
\hline & & $0 \%$ of principals are never able to empathy. & Not very good \\
\hline \multirow[t]{5}{*}{ Critical thinking } & \multirow[b]{5}{*}{$\| T P=J R=K D=S R=S L$} & $47.98 \%$ of most principals always have critical thinking & Excellence \\
\hline & & $31.73 \%$ of principals often have critical thinking. & Good \\
\hline & & $12.83 \%$ of principals sometimes have critical thinking. & Quite good \\
\hline & & $4.73 \%$ of principals rarely have critical thinking. & Less good \\
\hline & & 2.7\% of principals never have critical thinking & Not very good \\
\hline \multirow[t]{5}{*}{ Thinking about oneself } & \multirow{5}{*}{$\| \mathrm{TP} \equiv \mathrm{JR}=\mathrm{KD} \equiv \mathrm{SR} \equiv \mathrm{SL}$} & $28.35 \%$ of most principals always express thinking about oneself & Excellence \\
\hline & & 32.4\% of principals often express thinking about oneself. & Good \\
\hline & & $24.3 \%$ of principals sometimes express thinking about oneself. & Quite good \\
\hline & & 5.4\% of principals rarely express thinking about oneself. & Less good \\
\hline & & $9.45 \%$ of principals never express thinking about oneself. & Not very good \\
\hline
\end{tabular}

Fig. 1. Quality of principal authentic leadership.

Based on the figure 1, it is obtained results of the research on seven dimensions as the following.

\section{A. Self-awareness}

In the self-awareness dimension, there are 5 indicators namely meaning of values, identity, emotional management, motivation and goals. The first authentic leadership dimension, namely self awareness refers to the meaning directed to his life and how the meaning can give effects on the way a leader view himself and his time [15]. The five indicators are developed into 5 questions, among others are that our madrasah principals understand the meaning of self-value as a leader; our madrasah principals show self-identity as a leader; our madrasah principals can manage their emotional when facing any problems; our madrasah principals have high motivation in serving their roles; our madrasah principals have definite goals as a leader. Result of the research show that most of teachers, namely $64.3 \%$, stated that the principals always show selfawareness attitude; $28.4 \%$ of the teachers stated that the principals often show self-awareness attitude; $7.56 \%$ of the teachers stated that the principals sometimes show selfawareness attitude; $2.16 \%$ of the teachers stated that the 
principals rarely show self-awareness attitude and $1.08 \%$ of the teachers stated that the principals never show self-awareness attitude. Based on these research results, the highest percentage is in excellence category. The indicators developed in the statement have contained self-awareness aspects so it will obtain result on how the principal authentic leadership quality from the aspect of self-awareness. Self-awareness in the authentic leadership refers to the extent of leaders' awareness of self-strength, weakness and motivation as well as other perception on his leadership [16].

\section{B. Transparent Relationship}

Relationship transparency is how to make personal expression, such as actual, both thinking and feeling as well as share information in an open manner [16]. In the transparent relationship dimension, there are 2 indicators among others are open and honest which are developed into 4 statements, among others are our madrasah principals are open to others; our madrasah principals present themselves just the way they are; our madrasah principals are honest in their relationships with subordinates; our madrasah principals show frankly attitude when interacting with others. Results of the research show that most of the teachers, namely $62.2 \%$ stated that the principals show transparent relationship; $24.98 \%$ of the teachers stated that the principals often show transparent relationship; $11.48 \%$ of the teachers stated that the principals sometimes show transparent relationship; $0 \%$ of the teachers stated that the principals rarely show transparent relationship; and $1.35 \%$ of the teachers stated that the principals never show transparent relationship Based on the research results, the highest percentage is in excellence category. This transparent relationship shows the extent of the leaders to encourage openness with others by giving chances to present ideas, challenges and opinions. Honest are leaders and ones having no hidden agenda, having frankly attitude when interacting with others [17].

\section{Balanced Processing}

Balanced processing is objectively analyzing all relevant information for decision making, presenting balanced processing to seek opinions from others who may challenge one's own point of view [16]. In the balanced processing dimension, there are 2 indicators, namely processing information and multi-perspective. These two indicators are developed into 4 statements, among which are our madrasah principals process information in a balanced manner before making important decisions; our madrasah principals consider all available information to make decisions; our madrasah principals accept different views openly; our madrasah principals appreciate different points of view from their subordinates. The results showed that most of the teachers $(62.2 \%)$ stated that the principals always showed balanced processing, $29.03 \%$ of the teachers stated that the principals often showed balanced processing; $8.1 \%$ of the teachers stated that the principals sometimes showed balanced processing; $0.68 \%$ of the teachers stated that the principals rarely showed balanced processing; and $0 \%$ of the teachers stated that the principals never showed balanced processing. Based on results of this study, the highest percentage is in excellence category. This balanced processing shows that the extent to which leaders asks for sufficient opinions and points of view before making important decisions. The effective authentic leader will consider all options and contra views before taking a series of actions. Plans are thought out carefully and discussed openly with subordinates [17].

\section{Moral Perspective}

Internalized moral perspective is to present behavior that is guided by internal moral standards and values rather than by external pressure, words by deed [16]. In the moral perspective dimension, there are 2 indicators, namely self-regulation and decision making. These two indicators are developed into 3 statements, namely our madrasah principals are able to organize themselves based on moral values; our madrasah principals make decisions according to moral norms; our madrasah principals are able to make plans by considering moral values. The results showed that most of the teachers, namely $65.8 \%$ stated that the principals always showed a moral perspective' $28.8 \%$ of the teachers stated that the principals often showed a moral perspective; $4.5 \%$ of the teachers stated that the principals sometimes showed a moral perspective; $0.9 \%$ of the teachers stated that the principals rarely showed a moral perspective, and $0 \%$ of the teachers stated that the principals never showed a moral perspective. Based on the results of this study, the highest percentage is in the very good category in the empathy dimension, there are 4 indicators, including positive response, organized emotions, placing oneself, and being empathetic. Empathy consists of affective response, self-other awareness, emotion regulation, perspective taking, empathic attitudes [18]. These four indicators are developed into 4 statements, including our madrasah principals respond positively to other sensitivity; our madrasah principals are able to manage their emotions in dealing with other people; our madrasah principals are able to position themselves as empathetic people; our madrasah principals are able to be empathetic to other people. The results showed that most of the teachers, namely $64.23 \%$ stated that the principals were always able to be empathetic, $28.35 \%$ of the teachers stated that the principals were often able to be empathetic; $6.08 \%$ of the teachers stated that the principals were sometimes able to be empathetic; $1.35 \%$ of the teachers stated that the principals were rarely able to be empathetic, and $0 \%$ of the teachers stated that the principals were never able to be empathetic. Based on results of this study, the highest percentage is in excellence category.

\section{E. Empathy}

In the empathy dimension, there are 4 indicators, including positive response, organized emotions, placing oneself, and being empathetic. Empathy consists of affective response, selfother awareness, emotion regulation, perspective taking, empathic attitudes [18]. These four indicators are developed into 4 statements, including our madrasah principals respond positively to other sensitivity; our madrasah principals are able 
to manage their emotions in dealing with other people; our madrasah principals are able to position themselves as empathetic people; our madrasah principals are able to be empathetic to other people. The results showed that most of the teachers, namely $64.23 \%$ stated that the principals were always able to be empathetic, $28.35 \%$ of the teachers stated that the principals were often able to be empathetic; $6.08 \%$ of the teachers stated that the principals were sometimes able to be empathetic; $1.35 \%$ of the teachers stated that the principals were rarely able to be empathetic, and $0 \%$ of the teachers stated that the principals were never able to be empathetic. Based on results of this study, the highest percentage is in excellence category.

\section{F. Critical Thinking}

Critical thinking is an open point and reflective perception [18]. In the critical thinking dimension, there are 4 indicators including ideas, analytical, reflective, and skeptical. These four indicators are developed into 4 statements, namely our madrasa principals were critical to any ideas; our madrasa principals analyzes each problem; our madrasa principals were reflective to a proposal; our madrasa principals were skeptical of anything new. The results showed that most of the teachers, namely $47.98 \%$, stated that the principals always thought critically; $31.73 \%$ of the teachers stated that the principals thought critically, $12.83 \%$ of the teachers stated that the principals sometimes thought critically; $4.73 \%$ of the teachers stated that the principals rarely thought critically, and $2.73 \%$ of the teachers stated that the principals never thought critically. Based on results of this study, the highest percentage is in the excellence good category.

\section{G. Thoughts about Oneself}

Thought about oneself is about the desired disclosure, the amount of disclosure, positive and negative sides of oneself, accuracy-honesty to measure authentic leadership based on the point of view of existentialism [18]. In the thinking about oneself dimension, there are 2 indicators, namely positive side and negative side. These two indicators were developed into 2 statements, namely our madrasah principals expressed positive side about themselves; our madrasah leaders expressed negative side about themselves. The results showed that teachers, namely $28.35 \%$ stated that the principals always expressed thinking about themselves; $32.4 \%$ of the teachers stated that the principals often expressed thinking about oneself; $24.3 \%$ of the teachers stated that the principals sometimes expressed thinking about oneself; $5.4 \%$ of the teachers stated that the principals rarely expressed thinking about oneself; and $9.45 \%$ of the teachers stated that the principals never expressed thinking about oneself. Based on results of this study, the highest percentage is in the good category.

In addition, the research results regarding the quality of principal leadership can be seen from the mean percentage of each dimension that indicates the principal authentic leadership, which is as follows (figure 2).

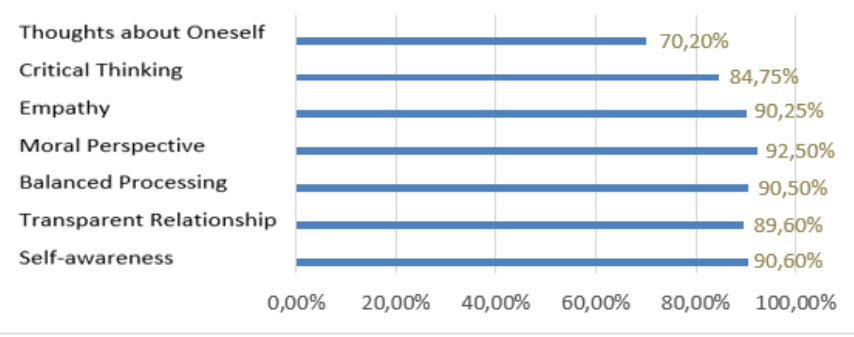

Fig. 2. Score percentage of authentic leadership dimension.

Based on the figure 2, it is obtained the score percentage of each dimension, namely self-awareness of $90.6 \%$, which shows that the interpretation is very good. Then, for the transparent relationship dimension, the percentage score is $89.6 \%$, which indicates that the interpretation is very good. Also, the balanced processing dimension is $90.5 \%$; the moral perspective dimension is $92.5 \%$; the empathy dimension is $90.25 \%$; and the critical thinking dimension is $84.75 \%$. The acquisition of the score percentage indicates very good interpretation. Then, for the thinking about oneself dimension, the percentage score is $70.20 \%$ which indicates good interpretation. The highest score was obtained from the moral perspective dimension. Referring to the theoretical study stating an internalized moral perspective, it can be seen that behavior is guided by internal moral standards and values rather than by external pressure, words with deeds [16]. Attitude in leadership shows that the extent to which leaders makes high level of standards for moral and ethical conduct. Authentic leaders have ethics, which the right ethics and justice to do and care about [17]. Ethics towards morality speech and weakening of work practices are rooted in ethical values, especially in such era like today which is described as post truth era, creating the existence of leadership such as authentic one as a utopian wish. Results of the research show that the quality of the moral perspective dimension in principal authentic leadership is very high compared to other dimensions, meaning that the principal authentic leadership ability is dominant in paying attention to morality, as a very important issue for a leader. Authentic leaders are seen as leaders who are very aware of themselves (very conscious) in thinking and acting and are perceived by others as people who are aware of their moral values and others; broad-minded and strong; Be aware of the context in which you are in, feel confident, have hope, optimism, resilience, and high moral character [10]. Furthermore, Dudka and Marjorie [19] reaffirmed the authentic leadership as leaders who have self-awareness, practice values and principles, and balance motivation so that values serve as external rewards. Moral values form the basis of authentic leadership. The morality values are used as a source of knowledge to identify authentic leadership. The lowest score percentage is in the dimension of thinking about oneself. In this dimension, it is seen in the way a leader's ability to express both his positive and negative sides. Thought about oneself is the desired disclosure, the amount of disclosure, one positive and negative sides, accuracy-honesty to measure authentic leadership based on the point of view of existentialism [18]. In the authentic 
leadership, being an authentic leader means continuing to strive to be oneself as reflected in the effort to personify managerial work, something that seems common as an aspiration, claim or belief [20]. This means that a leader must be able to judge himself in terms of both positive and negative aspects with honesty.

\section{CONCLUSION}

It is necessary for an existence of good principal authentic leadership as an effort to develop various potentials at schools so that they can improve school quality. The main dimensions in principal authentic leadership consist of self-awareness, transparent relationships, balanced processing, moral perspective, empathy, critical thinking, and thinking of oneself. Based on the survey, it shows different results but most of the dimensions have shown to be in the very good category. Therefore, it can be concluded that the principal authentic leadership is very good. By this general description of the principal authentic leadership, it is expected that it will be able to provide a descriptive picture of the extent to which the quality of authentic leadership possessed by school management, namely the principal of private madrasah aliyah schools in West Java.

\section{REFERENCES}

[1] L. Franken, "Islamic religious education in Belgian state schools: a postsecular perspective," J. Beliefs Values, vol. 39, no. 2, pp. 132-143, 2018.

[2] G. Driessen and M.S. Merry, "Islamic schools in the Netherlands: Expansion or marginalization?," Interchange, vol. 37, no. 3, pp. 201223, 2006.

[3] P. Anggraeni, Pengaruh Kepemimpinan Instruksional Dan Profesional Learning Communities Terhadap Kemampuan Mengajar Guru Dalam Rangka Mewujudkan Pembelajaran Yang Efektivitas: studi pada guru madrasah di bandung raya. Bandung: Universitas Pendidikan Indonesia, 2017.

[4] J. Berglund, "Islamic Religious Education in Muslim Schools: A Translation of Islam to the Swedish School System," in Religious Education in a Global-Local World, Springer, 2016, pp. 109-121.

[5] S.-R. Toor and G. Ofori, "Positive psychological capital as a source of sustainable competitive advantage for organizations," J. Constr. Eng. Manag., vol. 136, no. 3, pp. 341-352, 2010.
[6] C. Branson, "Effects of structured self-reflection on the development of authentic leadership practices among Queensland primary school principals," Educational Management Administration \& Leadership, vol. 35, pp. 225-246, 2007.

[7] K. Klenke, "Authentic leadership: A self, leader, and spiritual identity perspective,” Int. J. Leadersh. Stud., vol. 3, no. 1, pp. 68-97, 2007.

[8] A. Walker and C. Shuangye, "Leader authenticity in intercultural school contexts," Educ. Manag. Adm. Leadersh., vol. 35, no. 2, pp. 185-204, 2007.

[9] J. Eid, K. Mearns, G. Larsson, J.C. Laberg, and B.H. Johnsen, "Leadership, psychological capital and safety research: Conceptual issues and future research questions," Saf. Sci., vol. 50, no. 1, pp. 55-61, 2012.

[10] F.O. Walumbwa, F. Luthans, J.B. Avey, and A. Oke, Retracted: Authentically leading groups: The mediating role of collective psychological capital and trust. Journal of organizational behavior, vol. 32, pp. 4-24, 2011.

[11] A. Aria, P. Jafari, and M. Behifar, "Authentic Leadership and Teachers' Intention to Stay: The Mediating Role of Perceived Organizational Support and Psychological Capital.," World J. Educ., vol. 9, no. 3, pp. 67-81, 2019.

[12] M. Eriksen, “Authentic leadership: Practical reflexivity, self-awareness, and self-authorship,” J. Manag. Educ., vol. 33, no. 6, pp. 747-771, 2009.

[13] M. Krüger and J. Scheerens, "Conceptual perspectives on schoo leadership," in School Leadership Effects Revisited, Netherland Springer, 2012, pp. 1-30.

[14] E. Sallis, Total Quality Management in Education. London: Kogan Page Ltd., 2008.

[15] C. Fortin, L. Baron, and C. Renucci, "Authentic Leadership and Authenticity: An Existential Perspective," in Authentic Leadership and Followership, Springer, 2018, pp. 245-270.

[16] F.-I. Feng, "School Principals' Authentic Leadership and Teachers' Psychological Capital: Teachers' Perspectives.,” Int. Educ. Stud., vol. 9 no. 10 , pp. 245-255, 2016

[17] B.J. Avolio and W.L. Gardner, "Authentic leadership development: Getting to the root of positive forms of leadership," Leadersh. Q., vol. 16, no. 3, pp. 315-338, 2005.

[18] C.A. Lietz, Handbook of family resilience. New York: Bussines Media, 2013

[19] M.G. Dudka and E.T. Marjorie, "Introduction to the Adult Learning Special Issue: Embodying Authentic Leadership Through Popular Education at Highlander Research and Education Center," Adult Learning, vol. 27, pp. 94-97, 2016

[20] S. Sveningsson and M. Alvesson, Managerial Lives: Leadership and Identity in an Imperfect World. Cambridge: Cambridge University Press, 2016. 